\title{
POLSKI ZWIĄZEK SPORTOWY JAKO ORGANIZACJA W TEORII PÓL FLIGSTEINA I MCADAMA
}

\begin{abstract}
Abstrakt. W polskiej socjologii nie prowadzono badań dotyczących takiej organizacji jak Polski Związek Sportowy. W niniejszym artykule staram się wskazać istotne elementy z zakresu teorii i metodologii socjologii organizacji, które można stosować do badania związku sportowego. Korzystając głównie z teorii pól Fligsteina i Mc Adama (2016), wskazuję, po pierwsze, na usytuowanie Polskiego Związku Sportowego w polu instytucjonalno-prawnym. Po drugie, odnoszę się do struktury wewnętrznej związku, istniejącego w nim subpola władzy, a także pokazuję szereg innych istotnych zależności istniejących w związku sportowym, takich jak działanie „czynnika ludzkiego” w kreowaniu, zarządzaniu i trwaniu tego związku. Po trzecie, opisuję usytuowanie związku sportowego na mapie instytucjonalnej na mezopoziomie jego działania.
\end{abstract}

Słowa kluczowe: sport, organizacje sportowe, socjologia organizacji, teoria pól, instytucjonalizm.

\section{Wprowadzenie}

Na gruncie socjologii organizacji oraz socjologii sportu istnieje niewielka liczba badań nad organizacjami sportowymi. Co więcej, badacze socjologii sportu częściej podejmują badania poświęcone problematyce międzynarodowych organizacji, takich jak na przykład Międzynarodowy Komitet Olimpijski czy Europejska Unia Federacji Piłkarskich UEFA oraz Międzynarodowa Federacja Piłki Nożnej FIFA. Powodem tego jest skala wpływu, jaki te organizacje wywierają na społeczno-ekonomiczny wymiar współczesnej polityki i gospodarkę państw narodowych poprzez organizowanie wielkich imprez sportowych, takich jak igrzyska olimpijskie, mistrzostwa świata czy mistrzostwa Europy w piłce nożnej (Włoch 2017).

Warto przypomnieć, że studia nad organizacjami wywodzą się z dwóch różnych tradycji: europejskiej i amerykańskiej (Koza, Thoenig 1995). Europejskie rozważania nad problematyką organizacji mają swój początek w pracach Maxa Webera dotyczących biurokracji (Weber 2002) czy Emila Durkheima o podziale

${ }^{*}$ Instytut Filozofii, Socjologii i Dziennikarstwa, Wydział Nauk Społecznych, Uniwersytet Gdański, ul. Jana Bażyńskiego 4, 80-309 Gdańsk, e-mail: mankowskid@wp.eu 
pracy (Durkheim 2012). Nurt zapoczątkowany przez Webera w pracy dotyczącej biurokracji możemy znaleźć w późniejszych badaniach Michela Croziera (1967) nad francuską administracją publiczną. Kwestia podziału pracy, którą badał Durkheim (2012), pojawia się we wszystkich późniejszych pracach dotyczących organizacji. Amerykańskie badania nad organizacjami zapoczątkowano po II wojnie światowej (Koza, Thoenig 1995; Kolarska 1975). Zwraca na to uwagę William R. Scott: „Organizacje wyłoniły się jako rozpoznawalne pole badawcze w naukach społecznych w latach 50-ych XX wieku" (Scott 2004: 3). Obie tradycje badawcze łączą wspólne pytania, jakie stawiają: „Dlaczego społeczeństwa potrzebują organizacji i do czego im one służą? Jak organizacje wpływają na społeczną, polityczną i ekonomiczną strukturę? Czy organizacje są wyjątkowe dla kolektywnego działania?” (Koza, Thoenig 1995: 6). Zakres pytań dotyczących organizacji zwiększał się wraz z rozwojem samych organizacji w społeczeństwie (Hirszowicz 1967; Doktór 1976). To zaś powodowało, że studia nad organizacjami były badaniami, które łączyły różne dyscypliny naukowe: począwszy od psychologii, przez socjologię aż po antropologię z entografią (Katz, Kahn 1979; Sterniczuk, Żandarowski 1983; Kostera 2013). Obecnie studia nad organizacjami związały się z teoriami tak zwanego nowego instytucjonalizmu. Ten obszar teoretyczny jest najczęściej obecny w sposobach opisu i rozumienia organizacji czy instytucji.

W niniejszym artykule jako ramę teoretyczną stosuję teorię pól zaproponowaną przez socjologów Neila Fligsteina i Douga Mc Adama w książce $A$ Theory of Fields (2015). W tekście, wychodząc z założenia, że obecny porządek instytucjonalny zbudowany jest ,nie tyle na gruzach systemu komunistycznego, co raczej z tychże gruzów" (Marody 2011: 65), odnoszę się do miejsca Polskiego Związku Sportowego w systemie instytucjonalnym w sporcie w okresie PRL. Ten rys historyczny prowadzi mnie do opisu stanu obecnego. Za pomocą wspomnianej teorii pól szkicuję obraz Polskiego Związku Sportowego. Analiza dotycząca związku sportowego oparta jest na przeprowadzonym badaniu ${ }^{1}$, w którym stosowałem takie metody badawcze, jak: wywiady z aktorami społecznymi działającymi w organizacjach sportowych oraz analiza dokumentów ${ }^{2}$.

\section{Czym jest Polski Związek Sportowy?}

Terminem „Polski Związek Sportowy” (dalej też jako związek sportowy) określam organizację pozarządową, która $\mathrm{w}$ polskim systemie prawnym odpowiada za zarządzanie i organizację w obszarze konkretnej dyscypliny sportu

${ }^{1}$ Badanie było realizowane w ramach uczelnianego grantu dla młodych badaczy. Temat to Zwiazek sportowy. Socjologiczne badanie organizacji na przykładzie Polskiego Związu Hokeja na Lodzie.

${ }^{2}$ Dokumenty dostępne m.in. w związkach sportowych, w Archiwum Akt Nowych, na stronach internetowych. 
(lub - rzadziej - kilku dyscyplin; przykładem Polski Związek Narciarski, który odpowiada również za snowboard). Formą prawną związku jest stowarzyszenie stowarzyszeń. Tworzą go zrzeszone organizacje sportowe, takie jak: kluby sportowe i okręgowe związki sportowe (minimum trzy kluby sportowe mogą stworzyć związek sportowy ${ }^{3}$ ). W systemie sportu usytuowanie tej organizacji jest centralne. Wynika to z celów i zadań, które ma realizować. Do głównych celów i zadań należą: organizacja współzawodnictwa w danej dyscyplinie, rozwój dyscypliny, jej popularyzacja, tworzenie strategii dotyczącej dyscypliny, a także prowadzenie kadr narodowych. Polski Związek Sportowy jako organizacja łączy działania aktorów indywidualnych i zbiorowych. Odpowiada na zależność współdziałania jednostek i grup oraz kierunkuje to działanie w wyznaczonym celu. Struktura związku jest prawnie narzucona i może być tylko modyfikowana w określonych formatach. W związku z powyższym zasadne wydaje się ujęcie metateoretyczne zrównujące wszystkie związki sportowe pod egidą Polskiego Związku Sportowego i wykazanie jego działania w systemie instytucjonalnym w Polsce, co w dalszej części artykułu staram się zobrazować.

\section{Polski Związek Sportowy w Polskiej Rzeczpospolitej Ludowej}

Jak pisze Drucker (1999: 45): „Społeczeństwo we wszystkich rozwiniętych krajach stało się społeczeństwem organizacji, w którym większość, jeśli nie wszystkie zadania społeczne są wykonywane w organizacji i przez organizację", co powoduje, że sport przybiera wymiar instytucjonalny niezależnie od ustroju politycznego państw. W socjalistycznej Polsce również nie pominięto zagadnienia sportu i jego organizacyjnego wymiaru (Pasko 2012). W okresie między 1945 a 1950 rokiem wykształca się całościowa struktura organizacyjna dotycząca sportu w Polsce (zob. Pasko 2012; Kurkowska-Budzan, Stasiak 2016). Pasko podsumowując funkcjonowanie sportu w tej epoce, pisze: „Władze partii i państwa starały się przejąć pełną kontrolę nad życiem sportowym, by zapewnić realizację swoich celów. Wydarzenia sportowe i ich główni bohaterowie stawali się dla nich atrakcyjnymi «nośnikami» haseł propagandowych i wzorcem zachowań dla mas. Strategiczne decyzje o odpowiednim wykorzystaniu sportu i sportowców w działaniach propagandowych podejmowało najwyższe kierownictwo partii, a władze sportowe wykonywały te instrukcje" (Pasko 2012: 82), istniała zatem pełna zależność działania wszystkich organizacji sportowych od decyzji partii. Zarządzanie sportem miało charakter hierarchiczny i zależny od polityki państwa. Aby zarządzać sportem, władze socjalistyczne stworzyły agendy rządowe, którym podporządkowane były Polskie Związki Sportowe oraz kluby

${ }^{3}$ Regulacje pozwalające powołać związek sportowy określa m.in. ustawa o stowarzyszeniach (Dz.U. 1989, nr 20, poz. 104) oraz ustawa o sporcie (Dz.U. 2010, nr 127, poz. 857). 
sportowe. Chronologia istnienia agend rządowych była następująca: od 1950 do 1960 r. istniał Główny Komitet Kultury Fizycznej, który w 1960 r. przekształcono w Główny Komitet Kultury Fizycznej i Turystyki, aby w 1978 r. podzielić tę organizację na dwie: Główny Komitet Kultury Fizycznej i Sportu oraz Główny Komitet Turystyki, które połączono w 1985 r. w Główny Komitet Kultury Fizycznej i Turystyki. W 1973 r. stworzono pośrednią organizację na mocy ustawy o stowarzyszeniach z 1932 r. - Polską Federację Sportu (której członkami były polskie związki sportowe oraz wojewódzkie federacje sportu oraz pośredni członkowie, jak kluby sportowe). Polska Federacja Sportu była pośrednią organizacją między GKKFiS a związkami sportowymi. Polskie Związki Sportowe były stowarzyszeniami i stowarzyszały kluby sportowe, ale były zależne od PFS i wyższych agend (Głównego Komitetu oraz partii). Od 1973 r. merytorycznie (i po dziś dzień) odsunięto od sportu Polski Komitet Olimpijski (Pasko 2012). Istniały jeszcze różnego typu organizacje (np. Związek Polskich Związków Sportowych), ale należały one do otoczenia związków sportowych i nie posiadały realnego wpływu na ich działalność.

Jak wspomniano wyżej, w okresie PRL system sportu miał charakter hierarchiczny, gdzie najważniejsza była Polska Zjednoczona Partia Robotnicza. Wyznaczała ona kierunki działania sportu przez wyżej wymienione agencje rządowe, które następnie delegowały zadania na związki sportowe i kluby sportowe. Finansowanie sportu na poziomie reprezentacji narodowej, za którą odpowiedzialny był związek sportowy, wynikało z hierarchicznego układu i zgody władz na zwiększanie lub zmniejszanie kwot na daną dyscyplinę sportową (Pasko 2012). Co więcej, można zauważyć, że było to centralne i planowane działanie władz państwa w tworzeniu instytucjonalnego systemu sportu. Polskie Związki Sportowe, w przeciwieństwie do klubów, nie były zależne bezpośrednio od przedsiębiorstw państwowych, jednak jak wynika z prześledzonej dokumentacji, współpracowały głównie z przedsiębiorstwami, takimi jak Polskie Koleje Państwowe, Polskie Linie Lotnicze LOT w zakresie transportu sportowców. Związki współpracowały również z Instytutem Sportu oraz wyższymi uczelniami. Jednakże te relacje nie wynikały z zależności - czy to logistycznej, czy finansowej, jak w przypadku przedsiębiorstw i agend rządowych.

Polskie Związki Sportowe nie mogły same stanowić o rozwoju czy rozpadzie dyscypliny sportowej. Decyzje były podejmowane w innym ośrodku władzy. Takie hierarchiczne usytuowanie ma konsekwencje nawet we współczesnych czasach. Jeśli weźmiemy pod uwagę obecną strukturę finansowania związków sportowych, to niewielka ilość środków przeznaczonych na ten cel jest niezależna od agendy rządowej (ministerstwa). Według danych dostępnych z raportu ${ }^{5}$ minister-

${ }^{4}$ W okresie tzw. stalinizmu (1950-1956) doszło do likwidacji związków sportowych na rzecz sekcji w GKKF, jednakże od 1956 r. przywrócono Polskie Związki Sportowe (zob. Pa sko 2012).

${ }^{5}$ Raport dostępny: https://msit.gov.pl/pl/sport/badania-i-analizy/sport-wyczynowy/578,Sport-wyczynowy.html [dostęp 6.02.2018]. 
stwa sportu i turystyki można stwierdzić, że dziewięćdziesiąt procent związków sportowych utrzymuje się z dotacji rządowej. Nie oznacza to oczywiście, że po 1989 r. nie nastąpiła zmiana instytucjonalna w systemie sportu.

\section{Sport w okresie po transformacji}

Pierwszą dekadę okresu transformacji w obszarze sportu trafnie ilustruje w swoim tekście Kornelia Sobczak, pisząc: „,[G]dybym mogła zamieszczać obrazki - zamieściłabym przepiękne zdjęcie błota, w którym «Sokół utonął» ${ }^{6}$ i zakrzyknęła, zgodnie z obecną modą: Patrzcie, oto cała polska liga [cały polski sport - przyp. D. M.], całe lata dziewięćdziesiąte na jednym obrazku" (Sobczak 2017: 91-92). Taki błotny obraz ilustruje mozolne zmiany w polskim sporcie - jego wzloty i upadki. Krok po kroku, z gruzów socjalistycznego państwa polskiego wyłaniał się nowy instytucjonalny wymiar państwa, a w tym sportu. Warto nadmienić, że ,to historia danego społeczeństwa w znacznym stopniu określa warunki «specyficznej narodowej inkorporacji kapitalistycznych instytucji»" (Federowicz 2004: 26). Pozwala to traktować proces transformacji w sporcie jako soczewkę przemian zachodzących w społeczeństwie polskim. Specyfika polskiego środowiska sportowego zmierzyła się ze zmianami, które wpłynęły na status organizacji sportowych. Do głównych aspektów zmian zachodzących wraz z transformacją w obszarze sportu zaliczyłbym: 1) proces komercjalizacji, 2) odpolitycznienie i niezależność organizacji, 3) profesjonalizację zawodową, 4) szeroko rozumianą mediatyzację, 5) zwiększenie roli technologii, 6) biurokratyzację wynikającą ze zmian instytucjonalnych.

Spoglądając na procesy transformacji w sporcie, należy pamiętać, że te procesy się nie zakończyły. Zmiany zachodzące w Polsce zaraz po upadku socjalizmu skupiały się na innych obszarach życia społecznego. Z jednej strony sport stał się pasażerem na gapę transformacji. Istniał niezauważony w procesach transformacji. Z drugiej strony dotykały go wszystkie bolączki, które przenikały społeczeństwo polskie. Jak zauważa Elizabeth Dunn: „większość wysiłków skoncentrowano na restrukturyzowaniu sprywatyzowanych lub państwowych przedsiębiorstw poprzez reedukację menedżerów, jednak pracownicy wszystkich szczebli i konsumenci także stali się przedmiotem mniej lub bardziej subtelnych form «reedukacji»" (Dunn 2008: 19). Ta swoista ,reedukacja” dotyczy również omawianego obszaru sportu, który wynikał z odmiennego usytuowania i roli sportu w społeczeństwie kapitalistycznym niż w społeczeństwie socjalistycznym ${ }^{7}$.

${ }^{6}$ Tytuł prasowy z „Przeglądu Sportowego” z 21 kwietnia 1997 r.

7 Warto pamiętać, że w obu społeczeństwach sport i sportowcy byli i są wykorzystywani w celach propagandowych, reklamowych czy edukacyjnych. 
Pierwszym z wyżej wymienionych procesów jest komercjalizacja sportu. Relację sportu z biznesem można porównać do małżeństwa. Jest to związek nie z miłości, ale z rozsądku. W latach 90. XX w. w Polsce owo „małżeństwo” było trudne, papierowe i bardzo chimeryczne. Jeśli powołać się na twierdzenie, że „nowość jest cechą nie tyle danej sytuacji, ile naszej reakcji na nią", a „najbardziej typową organizacyjną reakcją na nowość jest znalezienie zestawu rutynowych działań, które można w danym przypadku zastosować" (March, Olsen 2005: 47), to należy zauważyć, że Polskie Związki Sportowe w nowym kontekście społeczno-gospodarczym przede wszystkim szukały rutynowych działań, aby przetrwać. W pierwszej kolejności, zarządzający związkami stosowali znane sobie praktyki, szukając pomocy w strukturach państwa. Szczególnie dotyczy to wszelkich form pozyskiwania środków finansowych na prowadzenie swojej działalności, poszukiwanie sponsorów dla związków sportowych pojawiło się stosunkowo późno. Aktorzy nowego kapitalizmu częściej byli zainteresowani sponsorowaniem klubów sportowych niż związków. Powodem takiego stanu rzeczy wydaje się problem z rozpoznaniem związku sportowego jako możliwego nośnika treści marketingowych. Proces komercjalizacji tych organizacji dokonał się dopiero w XXI w.

Zupełnie inaczej wyglądał proces profesjonalizacji i biurokratyzacji, które są miarą instytucjonalizacji sportu (Slack, Hinings 1992). W zachodniej cywilizacji ten proces można obserwować od lat 70. ubiegłego wieku - jako wzmożony i wywierający szczególny wpływ na tę dziedzinę życia społecznego. Instytucjonalny wymiar sportu legitymizuje go w świecie społecznym. Jak zauważa Przemysław Nosal: „instytucjonalna postać sportu staje się wtyczką podłączającą go do sieci relacji w obrębie systemu społecznego i reguluje jego status w obrębie tego ostatniego" (Nosal 2014: 155). Nie ma tu znaczenia, jaki ustrój polityczny panuje w danym systemie społecznym. Istotna różnica wynika z prowadzonej polityki i sieci relacji pomiędzy organizacjami sportowymi a ich środowiskiem. O ile polityka organizacyjna przed 1989 r. była zależna od polityki państwa, o tyle po transformacji związki sportowe musiały odnaleźć się na nowo. Dla zarządzających związkiem sportowym kluczowe było takie interpretowanie sytuacji polityczno-społecznej (a więc postrzeganie środowiska, w którym znajduje się związek), aby dostosować strategię działania do wynikających z niej zagrożeń i szans (threats and opportunities) (Slack, Hinings 1992). Kierując się zasadą, że im bardziej ,,jest rozwinięte społeczeństwo, im dalej postępuje podział pracy" (Sterniczuk, Żandarowski 1983: 208), tym bardziej się ono profesjonalizuje. Nietrudno dostrzec tę zmianę w związkach sportowych. Po pierwsze, po transformacji następuje odpływ ludzi ze sportu (w tym działaczy i sportowców), po drugie zmiany wymuszają zatrudnianie ludzi o nowych kompetencjach - m.in. w związku ze zwiększeniem roli mediów, komunikacji społecznej, ale również profesjonalnych trenerów, trenerów przygotowania fizycznego, fizjologów, psychologów. W związkach dochodzi do standaryzacji ról i pozycji zawodowych. 
Odchodzi się od woluntarystycznego uczestnictwa na rzecz profesjonalnych pracowników (Slack, Hinings 1992).

Czwartym aspektem zmian związanych z procesami transformacji jest mediatyzacja sportu. W PRL rola mediów w związku ze sportem ograniczała się do dyskursu propagandy lub czystej informacji (Loewe 2014). W potransformacyjnej Polsce media zaczęły odgrywać w sporcie zupełnie inną rolę. Pojawienie się na szerszą skalę mediów komercyjnych w świecie sportu wywarło wpływ na dookreślenie i spopularyzowanie wiedzy o komercyjnym potencjale sportu. W przypadku Polskich Związków Sportowych powiązanie z mediami przynosiło wymierne korzyści biznesowe. Coraz ważniejsze stały się prawa marketingu traktowane jako źródło dochodu. Sprzedaż praw medialnych do organizowanego współzawodnictwa (rozgrywki ligowe) czy organizowanych imprez rangi mistrzowskiej są tego przykładem. Zauważyć można, że działania podejmowane w jednym związku sportowym, w sposób mimetyczny były wdrażane w innych związkach (przykładem tego jest tworzenie strategii marketingowych, sprzedaż praw medialnych, tworzenie spółek prawa handlowego, lig zawodowych, itp.). Można tu zauważyć typowy przykład izomorfizmu, koncepcji zaproponowanej przez P. J. DiMaggio i W. W. Powella (1983). Jedna organizacja upodabnia się do drugiej ze względu na uwarunkowania środowiskowe (DiMaggio, Powell 1983; Slack, Hinings 1994). Warto zaznaczyć, że na gruncie polskiej socjologii nie przeprowadzono pod tym kątem żadnych analiz organizacji sportowych. Ponadto zmieniło się postrzegania kibica - odbiorcy wydarzeń sportowych. Obecnie większą część stanowią kibice, którzy uczestniczą w wydarzeniach sportowych za pośrednictwem mediów (Jakubowska 2014), oglądający wydarzenia sportowe np. w telewizji.

Zwiększenie roli technologii w sporcie było nieuniknione. Wraz z rozwojem technologii rozwijał i zmieniał się sport. Technologia i jej produkty wspomagają przede wszystkim szkolenie zawodników, ale także przyczyniają się do zmian przepisów, regulaminów i problematyzują kwestie związane z dopingiem. To w nieunikniony sposób związane jest ze zmianami w związkach sportowych i w zarządzaniu dyscypliną sportową.

Obecnie Polskie Związki Sportowe zdają się mieć ustabilizowaną pozycję w systemie sportu. Nie oznacza to, że nie przechodzą różnego rodzaju kryzysów - na przykład dotyczących prowadzonej polityki, odkrycia przypadków korupcji, stosowania przez zawodników dopingu. Kryzysy w otoczeniu wynikają również ze zmian polityki państwa i próby ingerowania w system sportu w Polsce ${ }^{8}$, a więc na przykład wyznaczania dyscyplin sportowych o wyższym lub niższym priorytecie w finansowaniu.

${ }^{8}$ Ingerencja państwa w system sportu datuje się od 2008 r., kiedy rozpoczęto pracę nad obecnie obowiązującą ustawą o sporcie. Następnie w latach 2011-2013 Ministerstwo Sportu i Turystyki próbowało zmienić system finansowania Polskich Związków Sportowych za sprawą algorytmu i podziału dyscyplin. Po części udało się to wprowadzić, jednak nie w wersji proponowanej przez Ministerstwo. 


\section{Teoria pól a związek sportowy}

Na zaproponowanym metateoretycznym poziomie Polski Związek Sportowy tworzy pewien lokalny porządek w obrębie danej dyscypliny sportowej. Badając związki sportowe, stwierdzić można, że są podobne do siebie. Działania aktorów są skierowane i zarazem konfrontują się z podobnymi celami i zadaniami. Zmienną jest dyscyplina sportu. Uznaję więc Polski Związek Sportowy za organizację sportową, którą w dalszej części opisuję, w zgodzie z propozycją Fligsteina i McAdama, jako pole działania strategiczne (pole instytucjonalne).

Teoria pól formułuje pogląd „,na temat tego, w jaki sposób tworzone, utrzymywane i przekształcane są lokalne porządki” (Fligstein 2009). Ten lokalny porządek rozumiany jest jako struktura i/lub system w obrębie pola. Traktując związek sportowy jako takie pole, mogę odnieść się do porządku, jaki ta organizacja tworzy. Włączając w to poziom mezo działań aktorów społecznych, jestem w stanie określić inne pola, które w różny sposób oddziałują na siebie. Ponadto, sama organizacja jest polem działania aktorów społecznych - tworząc strukturę władzy, konfrontując swoje działania i polityki, tworząc koalicje, jak również przekształcając samą strukturę pola. Zwrócić należy uwagę, że w przypadku związku sportowego istotne jest stworzenie ram, w obrębie których istnieje strategiczne pole działania.

Ramy te porządkują pole, tworząc strukturę. Struktura określa pozycje aktorów społecznych w polu oraz pozycję całego pola wobec zewnętrznego systemu pól instytucjonalnych (nazywam je również środowiskiem).

Aktorzy społeczni działający w polu dzielą się na dwie grupy: incumbents i challengers. Odpowiednio, pierwszą grupę stanowią aktorzy, których pozycja $\mathrm{w}$ polu jest dominująca, związana $\mathrm{z}$ posiadaną i reprodukowaną władzą. W przypadku związku sportowego byliby to aktorzy zarządzający związkiem (zarząd związku, komisja rewizyjna, biuro związku). Drugą grupę stanowią aktorzy będący w opozycji do władzy związkowej, którzy posiadają inną strategię działania i walczą o przejęcie władzy w obrębie pola. Opozycja w związku sportowym przybiera różne formy - może być całkowicie zdominowana przez rządzących związkiem, kooperować z nimi lub rywalizować o władzę. Wynika to m.in. z posiadanych przez grupę dominującą zasobów oraz proponowanych przez nią reguł działania organizacji. Można postawić pytanie, czy możliwa jest sytuacja, że grupa dominująca nie posiada opozycji? W przypadku związku sportowego zdaje się to niemożliwe. Narzucona przez zewnętrzne przepisy kadencyjność władz związku prowadzi do naturalnego powstawania grup, które chcą przejąć władzę w polu. Ta konfrontująca aktorów interakcja jest zasadnicza dla strategicznego pola działania. Strategiczność pola można utożsamiać z jednej strony ze strategiami dotyczącymi reprodukowania pozycji dominującej, z drugiej strony ze strategiami dotyczącymi przejęcia władzy. W obu przypadkach strategie te, w obrębie związku, dotyczyć będą propozycji 
działania i realizacji celów organizacji przez grupę posiadającą władzę. To czyni organizację tworem dynamicznym, procesualnym, podatnym na kryzysy, ale także taką, która wytwarza kooperację między jednostkowymi aktorami społecznymi tworzącymi w danym miejscu i czasie koalicje lub grupy. One zaś nastawione są na współdziałanie w polu i na zewnątrz pola.

Propozycja teoretyczna Fligsteina i McAdama bardzo dobrze ilustruje działalność Polskich Związków Sportowych. Wspomniane pozycje aktorów (incumbents i challengers) także przysługują zbiorowym aktorom społecznym (w przypadku związków sportowych klubom sportowym i okręgowym związkom sportowym, które tworzą tę organizację). Są one, używając terminologii wspomnianych socjologów, wewnętrznymi strategicznymi polami działania (polami instytucjonalnymi). Przedstawiciele tych organizacji (indywidualnie aktorzy społeczni) są wybierani do władz związku sportowego przez delegatów będących przedstawicielami klubów sportowych. W toku walnego zgromadzenia delegatów (czasem zwanego również walnym zebraniem delegatów), które raz na cztery lata przybiera formę sprawozdawczo-wyborczą, odbywają się wybory władz. Można więc stwierdzić za Fligsteinem, że „społeczna płynność tej sytuacji wskazuje na to, że możliwe są nowe układy" (Fligstein 2009: 290). W takiej sytuacji koalicje aktorów społecznych konfrontują się w celu przejęcia lub reprodukowania pozycji dominującej w polu. Reasumując, wybory decydują o tym, która grupa aktorów społecznych (delegatów) zajmuje pozycję w polu władzy. Tym samym uzyskuje możliwość prowadzenia własnej polityki w ramach działalności organizacji. Przegrani zajmują miejsce opozycji, co przyczynia się do ich mniejszego lub nawet żadnego wpływu na działania podejmowane przez organizację, którą tworzą.

Jeśli przyjrzymy się aktorom społecznym działającym w polu, to zwrócimy uwagę, że niezależnie, do której grupy należą, to podzielają oni normy i wartości, które konstytuują organizację. Jest to istotne, gdyż wszelkiego typu dokumentacja tworzona przez organizację odnosi się do regulaminów, kodeksów, zobowiązań i umów zawieranych przez aktorów społecznych. Można stwierdzić, że w podzielanych normach odbywa się gra pomiędzy aktorami społecznymi. Jest to istotne w kontekście granic pola i jego wewnętrznej gry. To rozgraniczenie pozwala na wyodrębnienie samostanowiącej o sobie organizacji w systemie pól instytucjonalnych. Zanim odniosę się do relacji zewnętrznych, warto przyjrzeć się strukturze zatrudnienia w związku sportowym.

Struktura zatrudnienia jest zróżnicowana i zależna od wielkości związku, jego zasobów finansowych oraz popularności dyscypliny sportowej. W każdym związku zatrudniony jest sekretarz generalny (ew. dyrektor biura), który zależnie od statutu organizacji może być członkiem zarządu z prawem głosu lub bez albo być poza zarządem. Co sprawia, że w grze pomiędzy grupą dominującą a grupą opozycyjną odgrywa ważną rolę. W większości sekretarze generalni nie posiadają prawa głosu w zarządzie, co powoduje, że usytuowanie ich pozycji w polu zdaje 
się być neutralne. Jeśli miałbym zastosować metaforę organizmu żywego, to porównałbym pozycję sekretarza generalnego do serca organizmu. Sekretarz jest łącznikiem między aktorami społecznymi występującymi w polu. Oprócz tego jest realizatorem postanowień zarządu związku. W pozycji sekretarza zderzają się dwie siły. Odgórna - idąca od władzy związku, oraz oddolna - będąca wyrazem zgłaszanych potrzeb przez takich aktorów, jak: trenerzy, zawodnicy, osoby współpracujące z kadrami narodowymi. Również sekretarz odpowiada za działanie względem otoczenia zewnętrznego, w którym funkcjonuje związek. Operacyjność stanowiska jest ogromna. W przypadku małych związków sportowych, jak na przykład Polskiego Związku Sportów Saneczkowych, taka osoba odpowiada za zdecydowaną większość działań i podejmowanych w związku decyzji. W przypadku dużego związku - jak na przykład Polskiego Związku Hokeja na Lodzie - zadania są delegowane na innych pracowników, tworząc dodatkową strukturę biura i zwiększając liczbę aktorów tworzących organizację.

Istotnym elementem w ujęciu teorii pól jest możliwość stworzenia mapy instytucjonalnych relacji zachodzących pomiędzy polem, jakim jest związek sportowy, a jego otoczeniem. Fligstein i McAdam wyróżniają w swojej teorii aktora, jakim jest governance unit, który może być usytuowany wewnątrz lub na zewnątrz danego strategicznego pola. W przypadku opisywanym governance unit - agenda rządowa - jest na zewnątrz pola instytucjonalnego, jakim jest związek sportowy. Pełni on istotną rolę. $\mathrm{Z}$ jednej strony jest agendą finansującą związek sportowy, z drugiej strony kontrolującą i legitymizującą, np. poprzez wydanie decyzji administracyjnej o przyznaniu statusu Polskiego Związku Sportowego ${ }^{10}$. Relacja zależności wynika z historycznego, hierarchicznego systemu sportu, który nadal stanowi, jako źródło finansowania, główną oś pomiędzy państwem a organizacją pozarządową, jaką jest związek sportowy. Z jednej strony wystąpiło „odpolitycznienie" - w tym sensie, że państwo bezpośrednio nie decyduje o dyscyplinach sportowych, dając niezależność działania związkom, z drugiej strony fakt, że państwo jest traktowane jako główne źródło finansowania, powoduje, że związki szukają osób politycznie, społecznie, lobbystycznie powiązanych z ośrodkiem władzy. Stąd między innymi prezesami związków stawali się politycy.

W systemie pól instytucjonalnych związek sportowy łączy relacja z nadzorującymi organizacjami międzynarodowymi. Polskie Związki Sportowe są członkami międzynarodowych federacji sportowych - to m.in. wymóg, aby posiadać status polskiego związku sportowego. Polski Związek Hokeja na Lodzie jest członkiem International Ice-Hockey Federation. Relacja związku sportowego

${ }^{9}$ Celowo używam tutaj metafory, wiedząc, że „stosowanie metafor powoduje, iż naszej percepcji umyka bogactwo zjawisk, które opisujemy za ich pomocą" (Kostera 1996: 39).

${ }_{10}$ Przykładem na to jest choćby decyzja ministra właściwego ds. kultury fizycznej nadająca status polskiego związku sportowego obecnie działającemu Polskiemu Związku Bobslei i Skeletonu, który odłączył się od Polskiego Związku Sportów Saneczkowych i w tej formie został nowym związkiem sportowym w roku 2013. 
do międzynarodowego jest podobna, jak w przypadku klubów sportowych będących członkami związków sportowych. To przedstawiciele narodowych federacji (związków) wybierają zarząd, komisje międzynarodowych organizacji. Również za pośrednictwem międzynarodowej federacji związki sportowe należą do Międzynarodowego Komitetu Olimpijskiego. Interesujące są także relacje pomiędzy narodowymi federacjami. Przykładem jest umowa pomiędzy Polskim Związkiem Sportów Saneczkowym a Bob- und Schlittenverband für Deutschland (Niemiecka Federacja Bobslei i Saneczkarstwa) dotycząca pomocy niemieckiej federacji w rozwoju saneczkarstwa w Polsce. Taka umowa jest również kontrolowana przez Międzynarodową Federację Saneczkarstwa (FIL), co ma gwarantować przejrzystość w rywalizacji sportowej. Inną relacją w międzynarodowym środowisku jest relacja ze światową komisją antydopingową (WADA).

Mapa relacji instytucjonalnych pomiędzy polami to mapa różnorakich relacji, w które wchodzi związek sportowy, zależnych od stopnia i ważności interakcji. Polskie Związki Sportowe posiadające sponsorów są bardzo silnie związane z ich polem instytucjonalnym, gdzie przepływ środków finansowych oraz cele, które realizuje związek dla swoich sponsorów, są ewidentnym przykładem na komercjalizację sportu. To „uzależnienie się” od sponsorów ma w relacji między związkiem a sponsorem swoją „,iemną” stronę, gdyż może uczynić związek częścią pola instytucjonalnego sponsora i to pole może prowadzić poprzez swoich przedstawicieli politykę związku, na przykład mieć wpływ na obsadę kadr narodowych, wybór trenera kadry, etc. Innym przykładem „uzależniającej” relacji, którą wymusza finansowanie związków przez agendę rządową, jest relacja z Centralnymi Ośrodkami Sportowymi (COS). Finansowanie zgrupowań kadr jest o tyle możliwe, o ile są one realizowane w Centralnych Ośrodkach Sportu, które podlegają pod agendę rządową (w przypadku polskim jest to ministerstwo sportu i turystyki). Podobnie jest z Centralnym Ośrodkiem Medycyny Sportowej (COMS), w którym tylko można przeprowadzać badania medyczne kadr narodowych. Wynika z tego, że państwowe organizacje typu COS czy COMS są za pomocą związków sportowych (jako pośredników) utrzymywane przez państwo. Innymi słowy, państwo finansuje związek, który otrzymane środki wydaje m.in. w COS czy COMS.

Polskie Związki Sportowe wchodzą w relacje z takimi organizacjami jak Akademie Wychowania Fizycznego, Polska Agencja Antydopingowa, jednostki samorządu terytorialnego, prywatne firmy logistyczne, firmy o profilu działalności marketingowej i public relations, stworzone przez związki sportowe spółki (np. tworzące ligi zawodowe), firmy zarządzające obiektami sportowymi, itp. Tworzenie takich map relacji pozwala na zobrazowanie sieciowego układu instytucjonalnych powiązań i zależności. Pozwala to na szersze ujęcie organizacji oraz jej środowiska, co dotychczas w polskiej socjologii nie było w żaden sposób badane ani analizowane. Teoria pól pozwala na opis tych relacji, ich stopniowalności oraz ukazanie siły grup tworzących koalicje i chcących przejąć lub utrzymać władzę w polu instytucjonalnym związku sportowego. 


\section{Podsumowanie}

Sport i nauki społeczne łączy wstydliwa przyjaźń (Jakubowska, Nosal 2017), co przejawia się między innymi w nielicznych badaniach dotyczących organizacji sportowych. Tak jakby ta część społecznej rzeczywistości istniała na marginesie społeczeństwa. Organizacje sportowe są równie istotne jak przedsiębiorstwa produkcyjne, korporacje finansowe, ponieważ nie istnieją w próżni społecznej, ale należą do systemu społecznego. Co więcej, refleksja nad tym obszarem życia społecznego pozwala opisywać i interpretować zachodzące w społeczeństwie zmiany, wykorzystując wiedzę na temat procesów profesjonalizacji, biurokratyzacji czy komercjalizacji. W socjologii, np. w teoriach nowego instytucjonalizmu, posiadamy teorie i narzędzia badawcze, które umożliwiają opisywanie obszaru życia społecznego, jakim jest sport, i jego instytucjonalnego wymiaru.

W niniejszym artykule starałem się zobrazować organizację, jaką jest Polski Związek Sportowy, na metapoziomie, który możemy empirycznie zastosować do analizy pojedynczych przypadków, jak np. Polski Związek Hokeja na Lodzie, Polski Związek Sportów Saneczkowych. Próbowałem wykazać złożoność relacji zachodzących wewnątrz i na zewnątrz organizacji sportowej, które łącznie przyczyniają się do zmiany jej charakteru i funkcjonowania. Struktura wewnętrzna oparta jest na opozycji aktorów społecznych posiadających władzę (w danym czasie) do aktorów próbujących tę władzę zdobyć. Sam związek sportowy jest organizacją niezależną, odrębną, ale bardzo uwikłaną w relacje ze środowiskiem, w którym istnieje. Ponadto związek sportowy jest organizacją, która profesjonalizuje środowisko pracy. Zatrudniani pracownicy muszą posiadać kwalifikacje do zarządzania sportem, co jest również wynikiem profesjonalizacji sportu jako takiego (Slack, Kikulis 1989; Slack, Hinings 1992). Pomimo istnienia wolnorynkowej gospodarki, postępującej komercjalizacji i modernizacji sportu, w znaczącej większości Polskie Związki Sportowe są uzależnione finansowo od państwowych dotacji. To zaś wzmacnia kontrolę zewnętrzną nad organizacją, powodując, że kontrola wewnętrzna traci swoje znaczenie i może powodować zbytnie uzależnienie się organizacji od zewnętrznych czynników.

Wspomniane na początku artykułu klasyczne pytania: Dlaczego społeczeństwa potrzebują organizacji? Do czego organizacje służą? Jak organizacje wpływają na społeczną, polityczną czy ekonomiczną strukturę? Czy organizacje są wyjątkowe dla kolektywnego działania? - są nadal aktualne. Socjologowie powinni stawiać je względem organizacji sportowych. Należałoby poszerzać wiedzę $\mathrm{z}$ tego zakresu, korzystając $\mathrm{z}$ dorobku socjologii organizacji czy teorii nowego instytucjonalizmu jako ram analitycznych dla badań empirycznych. 


\section{Bibliografia}

DiMaggio P. J., Powell W. W. (1983), The Iron Cage Revisited: Institutional Isomorphism and Collective Rationality in Organizational Fields, “American Sociological Review”, vol. 48 (2), s. $147-160$.

Doktór K. (1975), Socjologia organizacji, Ossolineum, Wrocław.

Doktór K. (1976), Socjologia organizacji: szkoły i kierunki badawcze, [w:] W. Morawski (red.), Organizacje. Socjologia struktur, procesów, ról, Państwowe Wydawnictwo Naukowe, Warszawa, s. $15-37$.

Drucker, P. F. (1999), Społeczeństwo pokapitalistyczne, Wydawnictwo Naukowe PWN, Warszawa.

Dunn E. C. (2008), Prywatyzujac Polskę, Wydawnictwo Krytyki Politycznej, Warszawa.

Durkheim E. (2012), O podziale pracy społecznej, Wydawnictwo Naukowe PWN, Warszawa.

Federowicz M. (2004), Różnorodność kapitalizmu. Instytucjonalizm i doświadczenie zmiany ustrojowej po komunizmie, Wydawnictwo IFiS PAN, Warszawa.

Fligstein N., McAdam D. (2015), A Theory of Fields, University Press, Oxford.

Hirszowicz M. (1967), Wstęp do socjologii organizacji, Państwowe Wydawnictwo Naukowe, Warszawa.

Jakubowska H. (2014), Gra ciałem. Praktyki i dyskursy różnicowania plci w sporcie, Wydawnictwo Naukowe PWN, Warszawa.

Jakubowska H., Nosal P. (red.) (2017), Socjologia sportu, Wydawnictwo Naukowe PWN, Warszawa.

Kolarska L. (1975), Teoria organizacji a cele organizacyjne. [w:] K. Doktór (red.), Socjologia organizacji, Ossolineum, Wrocław, s. 25-44.

Kostera M. (1996), Postmodernizm w zarządzaniu, Polskie Wydawnictwo Ekonomiczne, Warszawa.

Kostera M. (2013), Antropologia organizacji. Metodologia badań terenowych, Wydawnictwo Naukowe PWN, Warszawa.

Kostera M. (red.) (2007), Kultura organizacji. Badania etnograficzne polskich firm, Gdańskie Wydawnictwo Psychologiczne, Gdańsk.

Koza M., Thoenig J. (1995), Organizational Theory at the Crossroads: Some Reflections on European and United States Approaches to Organizational Research, „Organization Science”, vol. 6 (1), s. 1-8.

Koźmiński A. K. (red.) (1983), Współczesne teorie organizacji, Państwowe Wydawnictwo Naukowe, Warszawa.

Kurkowska-Budzan M., Stasiak M. (2016), Stadion na peryferiach, Universitas, Kraków.

Loewe I. (2014), Sport w mediasferze z perspektywy lingwisty, „Postscriptum Polonistyczne”, vol. 2 (14). s. 71-91.

March J. G., Olsen J. P. (2005), Instytucje. Organizacyjne podstawy polityki, Wydawnictwo Naukowe Scholar, Warszawa.

Marody M. (2011), Państwo a społeczeństwo, [w:] I. Krzemiński (red.), Wielka transformacja. Zmiany ustroju w Polsce po 1989, Wydawnictwo Naukowe Łośgraf, Warszawa, s. 65-74.

Morawski W. (red.) (1976), Organizacje. Socjologia struktur, procesów, ról, Państwowe Wydawnictwo Naukowe, Warszawa.

Nosal P. (2014), Technologia i sport, Wydawnictwo Katedra, Gdańsk.

Pasko A. (2012), Sport wyczynowy w polityce państwa 1944-1989, Avalon, Kraków.

Scott W. R. (2004), Reflections on a Half-Century of Organizational Sociology, "Annual Review of Sociology", vol. 30, s. xii-21.

Slack T., Hinings B. (1992), Understanding Change in National Sport Organizations: An Integration of Theoretical Perspectives, "Journal of Sport Management", vol. 6 (1), s. 14-13. 
Slack T., Hinings B. (1994), Institutional Pressures and Isomorphic Change: An Empirical Test, "Organization Studies", no. 15. s. 803-827.

Slack T., Kikulis L. M. (1989), The Sociological Study of Sport Organizations: Some Observations on the Situation in Canada, "International Review for the Sociology of Sport", no. 24, s. $179-199$.

Sobczak K. (2017), W składzie węgla i papy. Cudowne lata dziewięćdziesiąte polskiej pitki nożnej, „Kultura Współczesna”, nr 1, s. 89-103.

Sterniczuk H., Żandarowski M. Z. (1983), Socjologiczna teoria organizacji. [w:] A. K. Koźmiński (red.), Wspótczesne teorie organizacji, Państwowe Wydawnictwo Naukowe, Warszawa, s. 164-237.

Wallernstein I. (2007), Analiza systemów-światów. Wprowadzenie, Wydawnictwo Akademickie Dialog, Warszawa.

Weber M. (2002), Gospodarka i społeczeństwo, Wydawnictwo Naukowe PWN, Warszawa.

Włoch R. (2017), Organizacje sportowe, [w:] H. Jakubowska, P. Nosal (red.), Socjologia sportu, Wydawnictwo Naukowe PWN, Warszawa, s. 127-135.

\section{Strona internetowa}

https://msit.gov.pl/pl/sport/badania-i-analizy/sport-wyczynowy/578,Sport-wyczynowy.html [dostęp 6.02.2018].

\section{Dobrosław Mańkowski}

\section{POLISH SPORT FEDERATION. DRAFT FROM SOCIOLOGY OF ORGANIZATION}

Summary. There is no research on sports organizations as national sport federation in Polish sociology. In this paper I try to describe and show elements from theory and methodology of sociology of organization, which can be used to study national sport federation. Mainly, I use the theory of fields proposed by Neil Fligstein and Doug McAdam (2016). First of all, I point the place of national sport federation in the institutional and law field. Secondly, I draft the framework of organization. Also I point the sub-field of power and other significant relations inside organization. Thirdly, I describe the institutional map of relations of organization at mezo-level its operation.

Key words: sport, sport associations, sociology of organization, the theory of fields, institutionalism. 